\title{
Nükleer Tehlikeler ve Afet Yönetimi: Türkiye'de Durum Değerlendirmesi
}

\author{
Mehmet DOĞRULUK ${ }^{1}$, Ayhan DOĞAN ${ }^{2}$, Nalan KALKAN ${ }^{3}$ ve Murat KORKMAZ ${ }^{4}$
}

\begin{abstract}
Özet
Nükleer tehlikeler, atomun parçalanması ya da iki atomun birleşmesi ile açığa çıkan enerjinin kontrolsüz olarak yayılması ve çevreyi etkilemesi olarak tanımlanabilir. Radyoaktif materyallerin tutulduğu tesislerde oluşabilecek kazalar sonucunda radyasyon salınımı ortaya çıkabilmektedir. $\mathrm{Bu}$ tesislerde meydana gelen kazaların sebepleri arasında öngörülemeyen insan hatalarının yanı sıra deprem, sel ve tsunami gibi doğal afetler de yer almaktadır. Geniş bir çevreyi etkileyebilecek böylesi bir olayda, radyasyon salınımının durdurulması ve radyasyona maruz kalmanın engellenmesi gibi hayati önem taşıyan bir dizi eylem gerçekleştirilmesi gerekmektedir. Kısıtlı bir zaman diliminde ve sınırlı imkânlarla gerçekleștirilmesi gereken eylemleri kapsayan bu sürecin başarısı, afet öncesi korumaya yönelik yapılan hazırlık çalışmalarının etkinliğine bağlıdır. Öte yandan gerçekleştirilecek eylemlerin organizasyonu ve kaynakların yönetimi için coğrafi bilgi sistemleri (CBS) tabanlı karar destek sistemlerine ihtiyaç duyulmaktadır.
\end{abstract}

Bu çalışmada öncelikle radyasyon türleri ve radyasyonun canlılar üzerindeki etkileri açıklanmış, ardından nükleer ve radyolojik tehlikeler, komşu ülkelerde bulunan nükleer santrallerin oluşturduğu riskler de göz önüne alınarak Türkiye açısından değerlendirilmiştir. Ayrıca yeni kurulacak nükleer güç santralleri için deprem tehlikesinin belirlenmesi amacıyla yapılması gereken çalışmalar ve Türkiye'deki durum değerlendirilmiştir. Bununla birlikte nükleer ve radyolojik tehlikelere karşı afet yönetimi kapsamında ülkemizde gerçekleștirilen hazırlık çalışmaları incelenerek bir durum değerlendirmesi yapılmıştır.

Anahtar Kelimeler: Coğrafi Bilgi Sistemleri, Nükleer Kazalar, Radyasyon, Afet Yönetimi, Deprem

\section{Nuclear Danger and Disaster Management: Situation Assessment for Turkey}

\begin{abstract}
Nuclear hazards can be defined as fragmentation of the atom or the unfolding of energy generated by the combination of two atoms and influencing the environment. Nuclear hazards can arise as accidents that may occur in facilities where radioactive materials are kept. In these facilities, there are natural disasters such as earthquakes, floods and tsunamis as well as human errors that are not predictable among the causes of the accidents. In such an event, a number of vital actions need

\footnotetext{
1 Öğretim Görevlisi, Harita ve Kadastro Programı, Hacettepe Üniversitesi, Başkent OSB Teknik Bilimler MYO, Ankara İlgili yazar / Corresponding author: mehmet.dogruluk@hacettepe.edu.tr

2 Öğretim Görevlisi, Bilgisayar Programcılığı Programı, Hacettepe Üniversitesi, Başkent OSB Teknik Bilimler MYO, Ankara

3 Öğretim Görevlisi, İnşaat Teknolojisi Programı, Hacettepe Üniversitesi, Başkent OSB Teknik Bilimler MYO, Ankara
}

4 Öğretim Görevlisi, İklimlendirme ve Soğutma Programı, Hacettepe Üniversitesi, Başkent OSB Teknik Bilimler MYO, Ankara
\end{abstract}


to be taken, such as stopping the release of radiation and preventing exposure to radiation. The success of this process, which includes actions to be carried out in a limited time frame and with limited opportunities, depends on the effectiveness of the preparatory work towards pre-disaster protection. On the other hand, geographic information system (GIS) based decision support systems are needed for organization of actions.

In this study, firstly the types of radiation and the effects of radiation on living things are explained. Then, nuclear and radiological threats, posed by nuclear power plants are located in neighboring countries were evaluated taking into consideration Turkey. In addition, the studies to be done in order to determine the earthquake hazard for the newly installed nuclear power plants have been evaluated. However, preparatory studies carried out in our country in the scope of disaster management against nuclear and radiological hazards have been examined.

Keywords: Geographical Information Systems, Nuclear Accidents, Radiation, Disaster Management, Earthquake

\section{GİRİ̧}

Yaygın olarak bilinen ve uluslararası kurulușlarca kabul edilen tanımıyla "canlılar için fiziksel, ekonomik ve sosyal kayıplara neden olan, olağan yaşamı durduran ya da kesintiye uğratan, meydana geldiği bölgede yerel imkânlar ile baș edilemeyen ve dış yardım gerektiren her türlü doğal veya insan kaynaklı olay" afet olarak tanımlanmaktadır (Kadıŏlu, 2008). Bu tanından da anlaşıldığı üzere afetler doğa ve insan kaynaklı olarak sınıflandırılabilirler. Doğa kaynaklı afetler, oluşumları tabiat olaylarına dayanan afetlerdir. Dünyada en sık karşıllaşılan doğal afetler taşkınlar, depremler, orman yangınları, heyelanlar, firtınalar, volkan patlamaları, çığ düşmesi ve kuraklık olarak sıralanabilir. Özellikle son yıllarda yaşanan sanayileşme, nüfus artışı ve aşırı fosil yakıt tüketimi gibi nedenlerle küresel ısınmaya bağlı iklim değişikliğinin etkileri daha belirgin olarak hissedilmeye bașlamıștır. Bu etkiler orman yangınlarının, çölleșmenin, sel felaketlerinin ve erozyon gibi doğal afetlerin artmasına neden olmaktadır (Galip, 2017). İnsan kaynaklı afetler ise ulaşım kaynaklı kazalar, nükleer, biyolojik ve kimyasal madde kaynaklı kazalar ile büyük göçler gibi olayları kapsamaktadır. Ulașım kaynaklı kazalar, başta karayollarında meydana gelen kazalar olmak üzere günümüzde en sık karşılaşılan insan kaynaklı afetler türlerindendir (Işık vd., 2012; Kanlı \& Ünal, 2011). Öte yandan meydana gelme sıklı̆̆ bakımından son derece nadir görülen nükleer kaynaklı kazalar ise, kitlesel etkileri ve yıkım gücü bakımından değerlendirildiğinde insan kaynaklı afetler arasında önemli bir yere sahiptir. Özellikle son elli yılda, nükleer santrallerde meydana gelen kazalara bağlı olarak ortaya çıkan bu afetler, geniş bir coğrafyada, binlerce insanı aynı anda etkisi altına almış ve uzun süre devam eden büyük yıkımlara neden olmuştur (Günalp, 2017).

Diğer yandan son yüzyılda artan enerji ihtiyaçları, alternatif ve yenilenebilir enerji kaynaklarının ön plana çıkmasına neden olmuştur. Günümüzde en çok kullanılan enerji kaynağı fosil yakıtlardır (petrol, doğalgaz, kömür). Fosil yakıtların hızla tükendiği ve tüketiminin çevreye zarar verdiği göz önüne alındığında nükleer enerjinin alternatif bir enerji kaynağı olarak tercih edilebileceği görülmektedir. Nükleer enerji elde edebilmek için atomun parçalanması ile açı̆̆a çıkan ısı enerjisini elektrik enerjisine dönüștürebilen nükleer santraller geliștirilmiștir (Korkusuz, 2012). 20. Yüzyılın son çeyreğinde yaşanan petrol krizi nükleer santrallere olan ilgiyi daha da arttırmış, petrol ve doğalgaz gibi enerji kaynaklarına sahip olmayan ülkeler enerji bağımlılıklarını azaltmak için nükleer santral yapımına yönelmişlerdir (Eş, Mercan, \& Ayas, 2016). Günümüzde 30 ülkede toplamda 400'ün üzerinde nükleer santral faaliyet göstermektedir. Nükleer santrallerin sayısının artması ile birlikte bu santrallerde yakıt olarak kullanılan radyoaktif maddelere olan talep de artmıştır. Artan bu talep, radyoaktif maddelerin çevre üzerinde oluşturduğu riskleri arttırmıștır. 
Nükleer santrallerde meydana gelebilecek kazalar, her ne kadar insan kaynaklı afetler arasında oldukça nadir sıklıkta görülse de uluslararası ve kitlesel etkileri bakımından görmezden gelinemeyecek düzeydedir. Tüm bunlara ek olarak nükleer santrallerin kullanım sürelerinin aşılması ve terör saldırıları kapsamında kasıtlı olarak hedef alınması gibi tehlikeleri de bulunmaktadır (Özkan, 2016; Saygın, Küpeli, Küçükşahin, \& Demir, 2006). Bu nedenle radyoaktif maddelerin nükleer santrallerde kullanımı ve güvenliği konusunda uluslararası kuruluşlarca (Uluslararası Atom Enerjisi Ajansı, Avrupa Atom Enerjisi Topluluğu vb.) çeşitli güvenlik standartları belirlenmiştir. Bu standartlar genel olarak radyolojik sonuçları olabilecek kazaların önlenmesi ve bu kazaların meydana gelmesi durumunda ortaya çıkabilecek sonuçların hafifletilmesi gibi amaçları içermektedir (Hodaloğulları Vatansever, 2017). Ayrıca bu standartları benimseyen ve birçok ülkenin dahil olduğu çeşitli nükleer güvenlik sözleşmeleri oluşturulmuştur (Güneş, 2014). Sinırları içerisinde nükleer santral bulunmayan ülkelerin de dahil olabildiği bu sözleşmeler, nükleer maddelerin korunması, nükleer santrallerin inşası, işletilmesi, güvenliğinin değerlendirilmesi ve nükleer kaza durumunda işbirliği gibi konuları kapsamaktadır. Söz konusu sözleşmeler, taraf ülkeler için düzenleyici güvenlik ilkeleri ve çeşitli yükümlülükler oluşturmakla birlikte, nükleer tesislerin bulunduğu bölgedeki komşu ülkelerin güvenliğinin sağlanması ile ilgili doğrudan bir yaptırım mekanizması içermemektedir (Kocaoğlu, 2010). Her ne kadar nükleer santrallerin yapımında ve işletilmesinde güvenlik standartlarına uygun olarak tüm önlemler alınmış olsa da, öngörülemeyen insan hatalarının nükleer kazalara sebep olma olasılığı bulunmaktadır. Geçmiş deneyimler, olası bir nükleer kaza durumunda felaketin sınır ötesi etkilere sahip olduğu ve yakın çevresindeki ülkeleri olumsuz etkilediğini göstermiştir (Özkan, 2016). Bu ve benzer nedenler ile nükleer güç santrali bulunan bölgelerde olası nükleer ve radyolojik tehlikelere karşı hazırlıklı olmanın önemi daha da artmaktadır. Özellikle bu kapsamda oluşturulan erken uyarı sistemleri, söz konusu tehlikenin geniş bir çevreyi etkileyebilecek boyutlarda bir afete dönüşmeden önce komşu ülkelerin bilgilendirilmesi açısından son derece önem arz etmektedir.

Bu çalışmada yukarıda verilen bilgiler doğrultusunda; öncelikle nükleer ve radyolojik tehlikeler ile bunların canlılar üzerindeki etkileri açıklanmış ardından uluslararası ölçekte yaşanan nükleer ve radyolojik olaylar incelenmiştir. Bununla beraber nükleer ve radyolojik tehlikeler, komşu ülkelerde bulunan nükleer riskler de göz önüne alınarak Türkiye açısından değerlendirilmiştir. Ayrıca Türkiye gibi deprem riski yüksek olan ülkelerde yapılacak nükleer tesislerin yer tespiti ve alınması gereken önlemler hakkında temel bilgiler verilmiştir. Son olarak bu tehlikelere karşı Türkiye'de geliştirilen erken uyarı ve korunma sistemleri, afet yönetimi kapsamında incelenerek çeşitli öneriler getirilmiştir.

\section{RADYASYON TÜRLERİ VE CANLILAR ÜZERIDEKİ ETKILERİ}

Dünya üzerinde bulunan tüm canlılar, doğal radyoaktif maddelerden yayılan radyasyona ve evrenden gelen kozmik ışınlara maruz kalmaktadır (Erdoğan, 2017; Güden vd., 2012). İnsanlar, hava yoluyla, solunum ve sindirim yollarıla ve tükettiğimiz gıdalar (su ve diğer besinler) nedeniyle az veya çok miktarda radyasyondan etkilenmektedirler. Radyasyon hareket halindeki enerji olarak tanımlanır ve genel anlamıyla doğal radyasyon ve yapay radyasyon olarak iki bölümde incelenebilir. Şekil 1'de radyasyon kaynaklarının oransal dağılımı gösterilmektedir.

Doğal radyasyon kaynakları, yüksek enerjili kozmik ışın parçacıklarının atmosfere girmesi sonucunda oluşan ve yer kabuğunda yer alan hava, su, toprak, bitkiler ile diğer canlılarda bulunan radyoaktif çekirdekler olarak yer almaktadır (Gökharman vd., 2016). İnsan yapımı araç, gereç ve sistemler aracılığıyla elde edilen ve radyasyon üreten kaynaklar ise yapay kaynaklar olarak tanımlanmaktadır. Medikal, zirai ve endüstriyel amaçlarla kullanılan X ışınları, tüketici ürünlerinde kullanılan yapay radyoaktif maddeler ve nükleer güç üretiminden salınan radyoaktif maddeler başlıca yapay radyasyon kaynaklarıdır (Daşdağ, 2010; Erdoğan, 2017). 


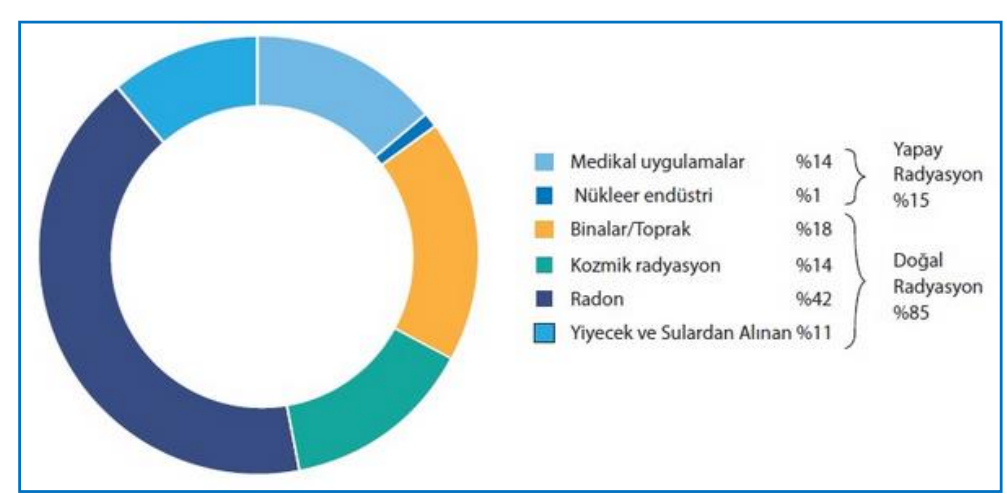

Şekil 1. Radyasyon kaynakları (UNSCEAR, 2012)

Radyasyonlar madde üzerinde oluşturdukları etkilere göre; iyonlaştırıcı ve iyonlaştırıcı olmayan olarak iki bölümde incelenmektedir. İyonlaştırıcı olmayan radyasyonlar bir atomdan veya molekülden bir elektronu tamamen koparabilmek için yeterli enerjiye sahip olmayan elektromanyetik radyasyon türüdür. Maddenin içinden geçerken yüklü iyonlar üretmezler. Bunlar Kızılötesi ışık, radyant ısı, morötesi ışık, görünür ışık, radyo dalgaları ve mikro dalgaları olarak sıralanabilir. İyonlaştırıcı olmayan radyasyon kaynaklarının oluşturduğu elektromanyetik alanların canlılar üzerindeki olumsuz etkilerini belirlemeye yönelik pek çok çalışma yapılmış ve halen de yapılmaya devam etmektedir (Çerezcı, Yener, \& Çerezcl, 2017; Ocaktan \& Akdur, 2008; Özgüner \& Mollaoğlu, 2006).

Atomları iyonlaştırabilecek kadar enerjiye sahip olan radyasyonlar iyonlaştırıcı radyasyon grubunda yer alır. İyonlaştırıcı radyasyonlar gama ışınları, X ışınları, alfa parçacıkları, beta parçacıkları ve nötronlar olarak gruplandırılır. İyonizasyon, herhangi bir maddede veya insanlar da dahil tüm canlılarda oluşabilen bir olaydır. Bu tür radyasyonlar, önlem alınmadığı takdirde tüm canlılara zarar verebilecek radyasyon grubundadır (Coşkun, 2011). Bu tür radyoaktif enerjiler; radyasyonun şiddetine maruz kalma süresine ve radyasyona maruz kalınan bölgeye bağlı olarak, herhangi bir zararlı etkisi olmadan geçip gidebilir, hücreye zarar verebilir veya hücreyi parçalayabilir. İyonlaştırıcı radyasyonun diğer etkileri, hücrelerde kimyasal toksinlerin üremesi ve hücrenin genetik bilgilerini taşıyan DNA zincirlerinde kırılmalar olarak görülebilir (Serhatlıŏlu vd., 2004).

Radyasyonun canlıların vücudunda yer alan hücre ve dokularda oluşturabileceği hasarlar, genetik hasarlar ve somatik hasarlar olarak iki bölümde incelenir. İyonlaștırıcı radyasyonun somatik etkileri; vücuttaki atom ve moleküllerin radyasyonla etkileşmesi ile organizma tarafından soğrulan enerji ölçüsünde ışına maruz kalan kişide meydana gelir. Bu etkilere, iyonlaştırıcı radyasyonun somatik etkileri denir (Daşdağ, 2010; Yaşar, Saygın, Kayan, \& Orhan, 2012). İyonlaştırıcı radyasyonların somatik etkileri radyasyona maruz kalan kişinin ömür süresi içinde ortaya çıkan etkilerdir. Somatik etkiler maruz kalınan toplam radyasyon dozuna, dozun alınma süresine ve radyasyonlara maruz kalan vücut kısmına bağlı olarak değişmektedir. Somatik etkileri erken etkiler ve gecikmiş etkiler olarak da sınıflandırmak mümkündür. Erken etkiler; belirtileri radyasyon alımının hemen ardından ortaya çlkmakta ve vücudun belli bir bölgesinin veya tamamının kısa sürede büyük oranlarda radyasyona maruz kalmasına neden olmaktadır. Genellikle istem dişı bir kaza sonucu meydana gelen erken etki hasarları kişiden kişiye farklılık göstermekle birlikte, kısa sürede veya birkaç hafta içerisinde önemli hasarlara, hastalıklara ve hatta ölümlere neden olabilmektedir. Bu etkiler; radyasyon kaynaklarının kaybedilmesi veya çalınması, kazalar veya herhangi bir yolla kontrol dışı kalmalarından oluşabilmektedirler. "Nükleer sızıntılar" bu gruba dahil edilebilir (Soykenar \& Coşkun, 2015; Yaşar vd., 2012).

Somatik etkiler gecikmiş etkiler olarak incelediğinde ise, radyasyon çalışanlarının kontrollü olarak aldıkları düşük doz ışınlanma etkilerinin yıllar sonra görülmesi olarak karşımıza çıkmaktadır. Bu 
etkilerin oluşumu, ışınlamalarda organizmanın oluşan hasarları onaramaması ve hasarların zamanla artması ile gerçekleşmektedir. Işınlanmaya maruz kalan kişilerde kalıtımsal bozukluklar, katarakt, saydamlık kaybı gibi göz hastalıkları oluşabileceği gibi, kanser gibi nedenlerle yaşam sürelerinde de bir kısalma söz konusu olabilir (Köklü, 2006; Yüce, 2016).

\section{RADYASYON KAYNAKLI KAZALAR VE AFETLER}

Dünyada radyasyon kaynaklı kazaların, genellikle doğal afetler ve insan hatalarından kaynaklandığı bilinmektedir. Bu anlamda dünya çapında yaşanmış nükleer kazalardan en bilinenleri İskoçya'da olan 1957 yılındaki “Windscale Nükleer Reaktörü Kazası”, Amerika Birleșik Devletleri'nde 1979 yılı yaşanan "Three Mile Island Nükleer Santral Kazası", şu anki Ukrayna'da (Eski SSCB) 1986'da yaşanan “Çernobil Nükleer Santral Kazası" ve en son olarak deprem sonucu oluşan tsunami nedeniyle 2011'de Japonya'daki "Fukuşima Nükleer Santral Kazası"dır (IAEA, 2005; Ülgen, Saygın, Or, Kumbaroğlu, \& Atiyas, 2011).

Tüm dünyada olduğu gibi ülkemizde de radyasyon kaynaklı kazalar ve afetlerden korunmak için birçok örgüt, kurum ve kuruluş çalışmalar yapmaktadır. Ülkemizde bu alanda faaliyet gösteren çok sayıda bakanlık ve kurum bulunmaktadır. Bunlar; Enerji ve Tabii Kaynaklar Bakanlığı, Afet ve Acil Durum Yönetimi Başkanlığı (AFAD) ve Türkiye Atom Enerjisi Kurumu (TAEK) olarak sıralanabilir. Türkiye'de afetlerin neden olacağı acil durumların etkin bir şekilde yönetilebilmesi amacıyla 2009 yılında AFAD kurulmuş ve afetlerle mücadelede bütünleşik afet yönetimi anlayışı benimsenmiştir. Böylece afet, acil olaylar ve sivil savunma ile ilgili hizmetlerin aynı merkez üzerinden koordinasyonunun yapılması, denetlenmesi ve bu hizmetlerle ilgili eğitim standartlarının oluşturulması amaçlanmıștır. Bu hedeflere uygun olarak, Türkiye'de meydana gelebilecek olası bir insan kaynaklı afet durumunda gerçekleştirilecek eylemleri planlamak amacıyla AFAD tarafından 2014 yılında Teknolojik Afetler Yol Haritası Belgesini yayınlamıştır (AFAD, 2014).

Birleşmiş Milletler bünyesinde faaliyet gösteren ve nükleer enerjinin barışçıl amaçlarla kullanılması amacıyla çeşitli standartlar belirleyen Uluslararası Atom Enerjisi Kurumu (IAEA), nükleer kazaların şiddetini belirlemede, Uluslararası Nükleer ve Radyolojik Olay Ölçeğini (INES) kullanmaktadır (Günalp, 2017) . INES ölçeğine göre nükleer olay seviyeleri Şekil 2'de yer almaktadır. Bunların anlamları aşağıda açıklanmıştır.

Seviye 7, Büyük Kaza; çok geniş alanlara yayılan, çevresel etkiler ve sağlık sorunları oluşturan, mücadele etmek için uzun vadeli ve planlı önlemler gerektiren kaza türüdür. Bu tip kazalar, atmosfere radyolojik olarak on binlerce tera becguerel I-131 (İyot 131) ile eşdeğerde radyoaktif madde salınımına yol açarlar. Böyle bir salınım, bazen birden çok ülkede etki gösterebilir ve sağlık üzerinde stokastik etkilerin yanında deterministik etkiler de oluşur. Uzun süreli çevresel etkiler de olasılık dahilindedir. Bu tür kazaların insanlar üzerindeki olumsuz etkilerini engelleyebilmek veya sınırlayabilmek için korunma amaçlı barınak veya tahliye gibi çeşitli önlemler alınması çok önemlidir. Şimdiye kadar Çernobil ve Fukuşima kazaları olarak iki adet seviye 7 kaza gerçekleşmiştir (Ülgen vd., 2011).

Seviye 6, Ciddi Kaza; planlı ve uzun vadeli önlemler alınmasını gerektirir. Çok miktarda radyoaktif madde salınımının geniş bir çevreye yayılarak insanlar ve çevre üzerinde olumsuz etkilere yol açtığı kazayı temsil eder. Ciddi kazalar, atmosfere radyolojik olarak binlerce tera becguerel I-131 (İyot 131) ile eşdeğerde radyoaktif madde salınımına yol açarlar. Bu tip bir salınım, bazen birden çok ülkede etki gösterebilir. Sağlık üzerinde stokastik ve deterministik etkiler oluşturabilir. Sığınma ve tahliye gibi çeşitli koruma amaçlı müdahale düzeyleri uygulanabilir. Şimdiye kadar ciddi kaza kapsamında kabul edilen tek kaza Kyshtym (Mayak) Kazasıdır (Ülgen vd., 2011).

Seviye 5, Geniş Sonuçları Olan Kaza; önceden planlanan koruma önlemlerinden bir kısmının uygulanmasını gerektirebilecek kazaları kapsar. Bu kaza türünde sınırlı oranda radyoaktif madde atmosfere salınır ve bireysel ölümler meydana gelebilir. Geniş sonuçları olan kazalar, atmosfere 
radyolojik olarak yüzlerce veya binlerce tera becguerel I-131 ile eşdeğerde radyoaktif madde salınımına yol açarlar. İngiltere'de 1957 yılında meydana gelen Windscale yangını ile 1979 yılında ABD’de meydana gelen Ǘç Mil Adası kazası bu tür kazalardandır (Ülgen vd., 2011).

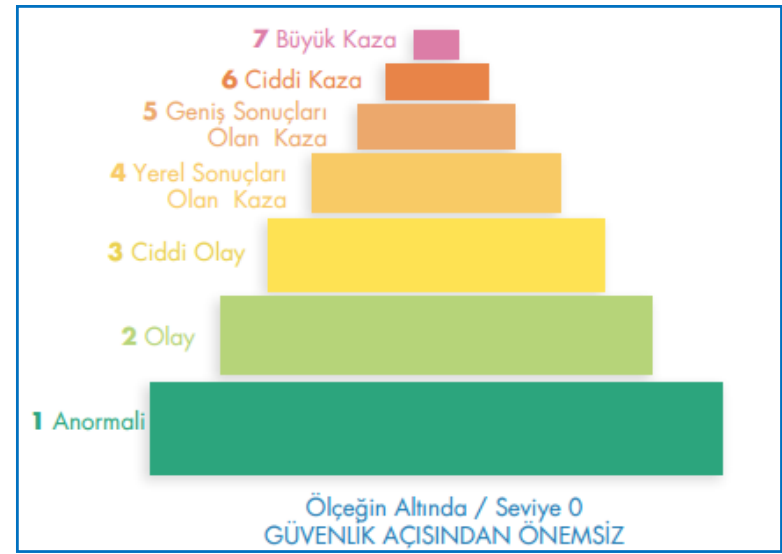

Şekil 2. INES ölçeğinde nükleer olayların hiyerarşisi (Ülgen vd., 2011)

Seviye 4, Yerel Sonuçları Olan Kaza; atmosfere radyolojik olarak yüzlerce tera becguerel I-131 ile eşdeğerde radyoaktif madde salınımına yol açarlar. Günümüze kadar iki tane yerel sonuçlu kaza meydana gelmiștir. Bunlar; Japonya'da meydana gelen Tokaimura Kazası ve Fransa'da meydana gelen Saint Laurent des Eaux Kazasıdır (Ülgen vd., 2011).

Seviye 3, Ciddi Olay; tesiste çalışan personelin, yllık izin verilen radyasyon sınırının on katını aşabilecek düzeyde radyasyon etkisine maruz kaldığı durumları ifade eder. Bu etkiler sonucunda ölüme neden olmayan yanık gibi düzenli sağlık problemleri oluşabilir. Bir tesiste $1 \mathrm{~Sv} / \mathrm{saat}$ 'in üstündeki bir hızda doza maruz kalma, tasarımda planlanmadığı gibi halkın etkilenme olasılığının düşük olduğu ciddi durumların oluşması, tesiste alınabilecek güvenlik tedbirlerinin kalmaması, kazaya yakın durumlar, zırhlı ve yüksek aktiviteli radyasyon kaynağının çalınması veya kaybolması, zırhlı ve yüksek aktiviteli radyasyon kaynağının uygun olmayan şekilde paketlenmesi gibi olayları ifade etmektedir.

Seviye 2, Olay; halk içerisinden herhangi bir kişinin $10 \mathrm{mSv}$ 'den daha fazla radyasyona maruz kalması, bir çalıșma ortamındaki doz hızının $50 \mathrm{mSv}$ /saatten fazla olması, çalıșanların her birinin yıllık izin verilen radyasyon dozunu așması, tesisin tasarımında düșünülmemiș önemli bir bulaşmanın olması, güvenlik zafiyeti oluşturabilecek önemli aksamalar, hasar almaksızın kaybolan yüksek aktivitedeki kaynak, cihaz veya taşıma paketi bulunması veya bunun uygunsuz paketlenmesi durumları olarak tanımlanır.

Seviye 1, Anomali; halk içerisinden herhangi bir kișinin yıllık kabul edilebilir düzeyin üstünde radyasyona maruz kalması, güvenlikte olușabilecek küçük ölçekli problemler, savunmanın önemli miktarda derinlemesine hasar görmediği durumlar, taşıma paketi veya cihazın çalınması ya da kaybolması durumları olarak tanımlanır (Ülgen vd., 2011).

INES ölçeğine göre günümüze kadar yaşanmış en büyük beş nükleer kaza ve bu kazaların etkileri ile ilgili bilgiler aşağıda kısaca açıklanmıştır.

- Çernobil Kazası, 1986 (Seviye 7)

Çernobil Nükleer Enerji Santralinde oluşan bu kaza Ukrayna'da meydana gelmiştir. Barışçl amaçlarla kullanılan nükleer enerji için tarihteki en büyük ölçekli kazadır. Bu kaza sonucunda, yangın ve buhar patlaması nedeniyle erime olmuş ve çok büyük miktarda radyoaktif madde salınımı gerçekleșmiştir. Kazada santralin 4 numaralı reaktörü patlamıș, binanın çatısı havaya uçmuş ve reaktör tamamen kullanılamaz hale gelmiștir. Bu patlama Ukrayna, Beyaz Rusya ve Rusya'da çeșitli olumsuz etkiler meydana getirmiștir. On gün içerisinde 1019 Bq radyonüklit 
etrafa yayılmıştır. Çok geniş bir çevreyi etkilemiş ve sağlık problemlerine yol açmıştır. Yayılan radyasyon Avrupa'ya kadar ulaşmıştır. Nüfusu yaklaşık on dört bin olan Çernobil ve nüfusu kırk dokuz bin olan Pripyat şehirleri tahliye edilmiş ve tesisin etrafında otuz kilometrelik bir genişlikte yasak bölge oluşturulmuştur. Bu kazanın yaklaşık 4000 kişinin ölümüne sebep olduğu ve 600.000 güvenlik ve kurtarma personeline etki ettiği düşünülmektedir (IAEA, 2005).

- Fukuşima Nükleer Kazaları, 2011 (Seviye 7)

Fukuşima nükleer kazası, 11 Mart 2011 tarihinde Sendai şehrinden $130 \mathrm{~km}$ uzaklıkta meydana gelen 8.9 büyüklüğündeki depremin etkisiyle oluşan tsunaminin santrali vurmasıyla oluşmuştur. Bu kaza neticesinde koruma ve yedek güç sistemlerinde büyük hasar meydana gelmiştir. Nükleer tesisin 1 numaralı reaktörlerinde aşırı ısınmalar ve kaçaklar oluşmuştur. Her bir reaktörde farklı seviyelerde kazalar oluşmuş, ancak genel durum ise seviye 7 olarak derecelendirilmiştir. Buna göre, üç tane reaktör 5. seviye, bir reaktör de 3. seviye olarak tespit edilmiştir. Nükleer santralin çevresinde 20 km'lik bir yasak bölge oluşturulmuştur. Bu kazadan etkilenen kurtarma ve güvenlik personeli sayısının 23.000 kişi olduğu düşünülmektedir (Ergün ve Polat, 2012). Fukushima Nükleer kazası, Çernobil'de meydana gelen kaza ile aynı seviyede olmasına rağmen, bu kazanın halk sağlığı bakımından ortaya çıkardığı sonuçlar Çernobil kazası ile kıyaslanamayacak kadar küçüktür (NEI, 2012).

\section{- Kyshtym Kazası, 1957 (Seviye 6)}

Bu kaza Sovyetler Birliği'nde bulunan askeri bir tesiste 29 Eylül 1957 tarihinde Mayak bölgesinde olmuştur. Kaza, nükleer atık işleme tesisinde bulunan soğutma sisteminde arıza nedeniyle onlarca ton radyoaktivitedeki maddenin salınımına yol açan buhar patlaması sonucu ortaya çıkmıştır. Kazanın olduğu bölgedeki etkisi tam olarak tespit edilememiştir. Bu kaza günümüze kadar gerçekleşen ilk ve tek seviye 6 kazadır (Ülgen vd., 2011).

\section{- Üç Mil Adası kazası, 1979 (Seviye 5)}

Bu kaza ABD’nin Pensilvanya yakınındaki Üç Mil Adası TMI-2 nükleer santralinde 29 Mart 1979 tarihinde meydana gelmiştir. Gerek operatör gerekse tasarımdaki hataların bir araya gelmesiyle, aşamalı olarak kısmi erime gerçekleşmiş ve radyoaktif gazların atmosfere salınmasıyla kaza devam etmiştir. Çalışanlardan ve çevredeki kişilerden bilinen herhangi bir ölüm olayı olmamakla birlikte, Amerika Birleşik Devletleri'ndeki ticari nükleer santraller içerisindeki en önemli kaza olduğu bilinmektedir (Ülgen vd., 2011).

\section{- Windscale yangını, 1957 (Seviye 5)}

Bu kaza, İngiltere'deki askeri bir tesiste 10 Ekim 1957 tarihinde meydana gelmiștir. Söz konusu kaza, tesisteki hava soğutmalı bir reaktörde bulunan yavaşlatıcıda meydana gelen problemler sonucu oluşmuştur. Bu kazada toz halindeki radyoaktif maddeler çevreye salınmıştır (Ülgen vd., 2011). 1979'daki TMI-2 Kazasından sonra, nükleer santrallerde oluşabilecek şiddetli kazalara neden olan belirsizlikleri azaltmak için çok sayıda araştırma yapılmıştır (Bodansky, 2007).

Nükleer reaktör tasarlarken en öncelikli amaç, bu reaktördeki güvenlik sınırlarının aşılmadan gerçekleştirilebilecek olan muhtelif olaylara dayanabilecek yapıda olmasıdır. Örnek olarak ilk devrede soğutucu kaybına neden olan bir kazanın neticelerinin belirlenmesi ve kabul edilebilir düzeyde yeterli olması esasına dayalıdır (Ülgen vd., 2011).

\section{AFET YÖNETIMI ÇERÇEVESINDE NÜKLEER VE RADYOLOJIK TEHLIKKELER}

Nükleer ve radyolojik tehlikeler, atomun parçalanması ya da iki atomun birleşmesi halinde açığa çıkan enerjinin kontrolsüz olarak yayılması ve radyasyon güvenliği standartları uyarınca belirlenen sinırlardan daha fazla radyasyon dozunun alınması olarak tanımlanabilir. Sınır ötesi etkilere sahip olan bu yayılmalar; radyoaktif materyallerin tutulduğu nükleer, endüstriyel ve tıbbi 
tesislerde oluşabilecek kazalar nedeniyle ortaya çıkabilmektedir. Ayrıca bu tesislerin bulunduğu bölgelerde meydana gelen deprem, sel ve tsunami gibi doğal afetlerin neden olduğu yıkımlar sonucunda da radyasyon salınımı meydana gelebilmektedir. Nükleer silah denemeleri ve radyoaktif maddelerin taşınması sırasında oluşan sızıntılar da nükleer ve radyolojik yayılmalara neden olan etkenler arasındadır (Özkan, 2016). Radyoaktif maddelerin çevreye yayılması, radyasyonun zararlı etkilerinin oluşturabileceği kitlesel tehlikeler arasında ilk sırada yer almaktadır. Radyoaktif yayılma, meteorolojik şartların da etkisiyle birkaç günde hatta saatler içinde gerçekleşebilir ve kilometrelerce uzaktaki bölgeleri etkisi altına alabilir (Değer, 2010). Çevredeki tüm canlıları etkileyebilecek böylesi bir olayda en büyük tehditlerden biri, özellikle civarındaki insanların radyoaktif serpintilerin etkilerine maruz kalmasıdır. Radyoaktif serpintiyle kontrolsüz olarak salınan radyonüklitler atmosfere dağılarak, suya, toprağa, bitkilere, hayvanlara ve en nihayetinde insana kadar ulaşabilmektedir. Böylesi bir olayda, radyasyon salınımının durdurulması ve radyasyona maruz kalmanın engellenmesi gibi hayati önem taşıyan bir dizi eylem gerçekleştirilmesi gerekmektedir (Gökeri, Gülay, \& Demirel, 2012). Kısıtlı bir zaman diliminde ve sınırlı imkânlarla gerçekleştirilmesi gereken eylemleri kapsayan bu sürecin başarısı, tahmin ve erken uyarı gibi afet öncesi risk azaltma ve hazırlık çalışmalarının etkinliğine bağlıdır. Dahası, hazırlık çalışmalarından müdahale ve iyileştirme sürecine kadar afet yönetimi kapsamında gerçekleştirilecek eylemlerin tümü ancak Coğrafi Bilgi Sistemleri (CBS) tabanlı bir karar destek sistemi yardımıyla yürütüldüğünde beklentilere karşılayabilir (Arca, 2012). Afet öncesi riskli bölgelerin belirlenmesi ve gerekli önlemlerin alınabilmesi için afetin etkili olacağı bölgenin fiziksel özellikleri ve nüfus yoğunluğu gibi mekânsal verilere ihtiyaç duyulmaktadır. Ayrıca bu veriler yardımıyla afet senaryoları ve müdahale stratejileri geliştirilmesine yönelik planlama çalışmaları yapılmaktadır. CBS, afet yönetimi kapsamında yapılan planlama çalışmalarında çeşitli verilerin birbirleri ile olan ilişkilerini kullanarak mekânsal analizler yapılmasına imkân tanımaktadır. Etkin bir veri paylaşım aracı olması, depolanan mekânsal verilerin güncellenebilmesi, karmaşık verileri katmanlar şeklinde depolaması sayesinde hızlı analiz yapabilmesi, afet türlerine göre farklı analizlerin yapılabilmesi gibi özellikleri nedeniyle CBS, afet yönetiminin tüm aşamalarında kullanılabilecek etkin bir araçtır (Demirci, 2004).

Afet yönetimi, doğal ve insan kaynaklı afetlere sebep olabilecek tehlikelerin afet yaşanmadan önce belirlenerek olası zararları en düşük düzeyde tutacak önlemlerin alınmasını için yapılan çalışmalar bütünü olarak tanımlanabilir (Erkal \& Değerliyurt, 2009). Modern afet yönetim sistemi; zarar azaltma, hazırlıklı olma, müdahale ve iyileştirme şeklinde sıralanan dört ana evreden oluşmaktadır (Kadığlu, 2008). Söz konusu dört evrede gruplanan ve süreklilik göstermesi gereken faaliyetler "afet döngüsü" veya "afet zinciri" olarak isimlendirilen bir döngü oluşturur (Şekil 3). Bir önceki aşamanın bir sonraki aşamanın başarısını etkilediği bu döngüde gerçekleştirilen faaliyetler iç içe geçmiş durumdadır (Kadıoğlu, 2008; Varol ve Kaya, 2018).

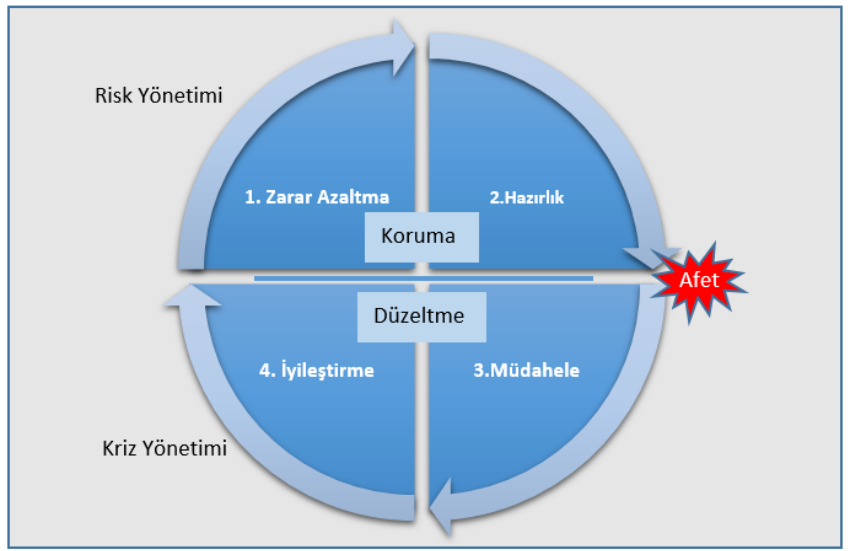

Şekil 3. Modern afet yönetim sistemi ve evreleri (Kadıŏlu, 2008) 
Modern afet yönetimi yaklaşımında afet gerçekleşmeden önce yapılan çalışmaları kapsayan süreç "risk yönetimi" olarak tanımlanmaktadır. Risk yönetimi, afetin gerçekleşme riskini azaltmayı veya afetin etkilerini hafifletmeyi hedefleyen önlemlerin alındığı süreçtir. Afet anında ve sonrasında yapılacak çalışmaları içeren süreç ise "kriz yönetimi" olarak tanımlanmaktadır. Kriz yönetimi süreci, afet anındaki gerçekleştirilen müdahale, kurtarma ve yeniden yapılanma çalışmalarının gerçekleştirildiği süreçtir (Büyükkaraciğan, 2016). Geçmişten günümüze kadar edinilen deneyimler, afet sonrası süreçte gerçekleştirilen çalışmalara ağırlık veren geleneksel afet yönetimi yaklaşımının özellikle büyük ölçekli afetlerde yetersiz kaldığını göstermiştir. Bu nedenle afetlerin karmaşık etkileri ile mücadele edebilmek için afet yönetiminin risk yönetimi perspektifinden ele alınması gerekmektedir. Modern afet yönetim sistemlerinde afet öncesinde yapılan çalışmalar afetin risklerini ortadan kaldırmayı, azaltmayı veya paylaşmayı hedef almaktadır (Özmen \& Özden, 2014).

Nükleer ve radyolojik tehlikelere karşı afet risk yönetimi kapsamında yürütülen çalışmaların başında erken uyarı sistemleri gelmektedir. Erken uyarı, "insanları tehlikelere karşı zamanında ve gerektiği gibi davranmalarına imkân tanıyacak şekilde haberdar etmek" şeklinde tanımlanabilir (Kadıŏlu, 2008). Nükleer güç santrallerinde meydana gelebilecek herhangi bir kaza durumunda radyasyonun doğrudan etki gösterebileceği bir maruz kalma alanı oluşmaktadır. Radyasyon açısından en riskli bölge olarak tanımlanan ve genellikle insanlarda en ciddi hasarı oluşturan maruz kalma alanının belirlenmesinde, radyasyon kaynağına uzaklık ve radyasyon doz miktarı oldukça önemlidir. Ayrıca risk altındaki bölgelere uygulanacak müdahale düzeyi (sığınma, tahliye vb.) de radyasyon dozunun doğru ölçülmesine bağlıdır (Ekşi, 2017). Hem müdahale seviyesinin hem de maruz kalma alanının belirlenmesinde bir ölçüt olarak kullanılan radyasyon dozu, sürekli doz ölçümü yapan istasyonlar yardımıyla belirlenebilmektedir. Erken uyarı sistemleri, bu istasyonlarda ölçülen radyasyon dozundaki artışın algılanması esasına göre çalışmaktadır. Çernobil nükleer santral kazasından sonra 1986 yılında "Nükleer Kaza Halinde Erken Bildirim Sözleşmesi” kabul edilmiştir. Bu sözleşmeyle kazanın meydana geldiği taraf ülkeye, kazanın zamanını, yerini, radyoaktif madde türünü, salınım miktarını ve benzer önemli bilgileri raporlama zorunluluğu getirilmiştir. Türkiye'nin ve yakın komşularının (Ermenistan, Yunanistan, Bulgaristan, Irak) da aralarında bulunduğu 101 ülkenin imzaladığı sözleşme ile birlikte, sıra dışı radyoaktif madde salınımının söz konusu olduğu durumları önceden haber verecek bir erken bildirim sisteminin kurulması amaçlamaktadır (Güneş, 2014). Sözleşmenin ardından nükleer santrallerde oluşabilecek radyasyon sızıntılarının erken haber alınabilmesi amacıyla pek çok ülkede ölçüm istasyonlarının kurulması yönünde çalışmalar başlatılmıştır.

\subsection{Mevcut Nükleer Santrallerin Oluşturduğu Tehlikeler}

Komşularımızın topraklarında kurulu bulunan nükleer güç santralleri, Türkiye toprakları üzerinde kaza riskleri oluşturmaktadır. Şekil 4'de de görüldüğü üzere, Ermenistan'da bulunan Metsamor Nükleer Güç Santrali doğu sınırımıza yaklaşık 16 km uzaklıkta, Bulgaristan'da bulunan Kozloduy Nükleer Güç Santrali ülkemizin kuzey batı sınırına yaklaşık $300 \mathrm{~km}$ uzaklıkta ve Romanya'daki Çernavoda Nükleer Güç Santralleri ise ülkemizin kuzey batı sınırına yaklaşık 250 km uzaklıkta bulunmaktadır.

Sınırlarımıza yakın konumdaki nükleer santraller içerisinde en tehlikeli olan Ermanistan'da bulunan Metsamor Nükleer Güç Santralidir (Şekil 5). Metsamor, başkent Erivan'ın yaklaşı 40 km batısında bulunmaktadır. Metsamor Nükleer Santralinin birinci ünitesi 1976, ikincisi ise 1979 yılında kurulmuştur. Metsamor Nükleer Güç Santralindeki nükleer reaktörlerin koruma kabı olmayıp günümüzde artık kullanılmayan bir sisteme sahiptir (Yüksel, 2014).

Metsamor Nükleer Santrali'nin bir başka tehlike arz eden yönü ise birinci derece deprem bölgesinde bulunuyor olmasıdır. Bu nedenle birçok bilim adamı tarafından yapımına karşı çıkılmış olmasına rağmen bu uyarılar dikkate alınmayarak santral inşa edilmiştir. Gerek birinci derece deprem bölgesinde olması gerekse çok eski teknoloji ile üretilmiş olması Metsamor Nükleer 
Santrali'ni bölgenin ve dünyanın en tehlikeli nükleer santrali haline getirmektedir. Bu santralde oluşabilecek bir kaza sonrası ülkemizin nasıl etkileneceğini belirlemek amacıyla TAEK, 2012 yılında teknik bir rapor hazırlamış ve olası riskleri ve tedbirleri belirlemeye çalışmıștır.

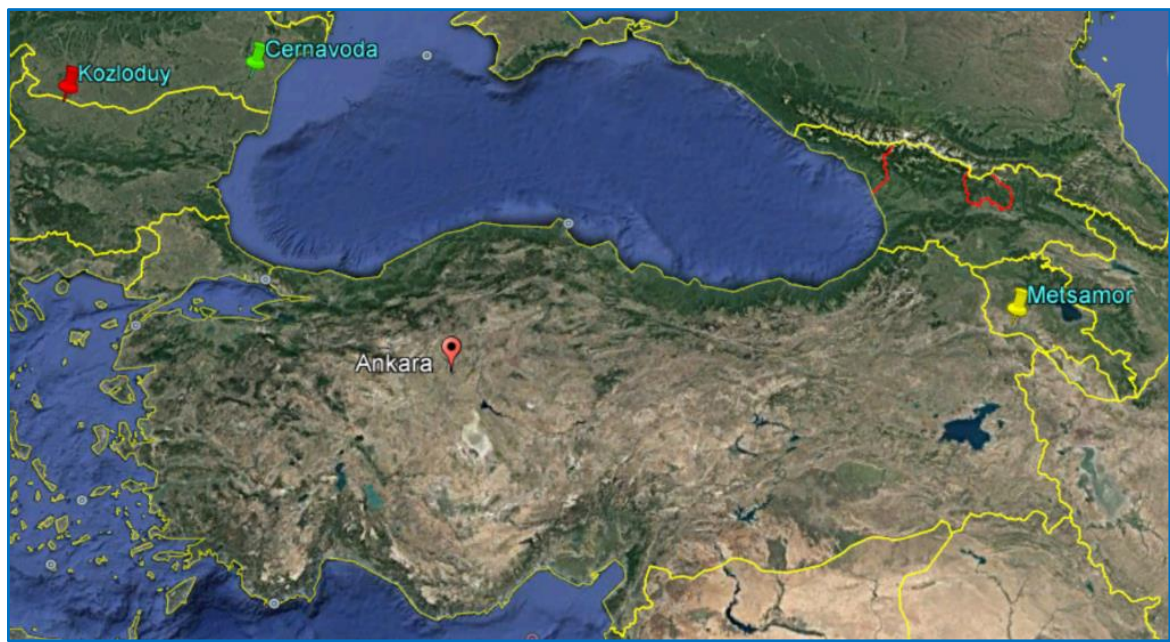

Şekil 4. Komşu ülkelerde bulunan nükleer santraller

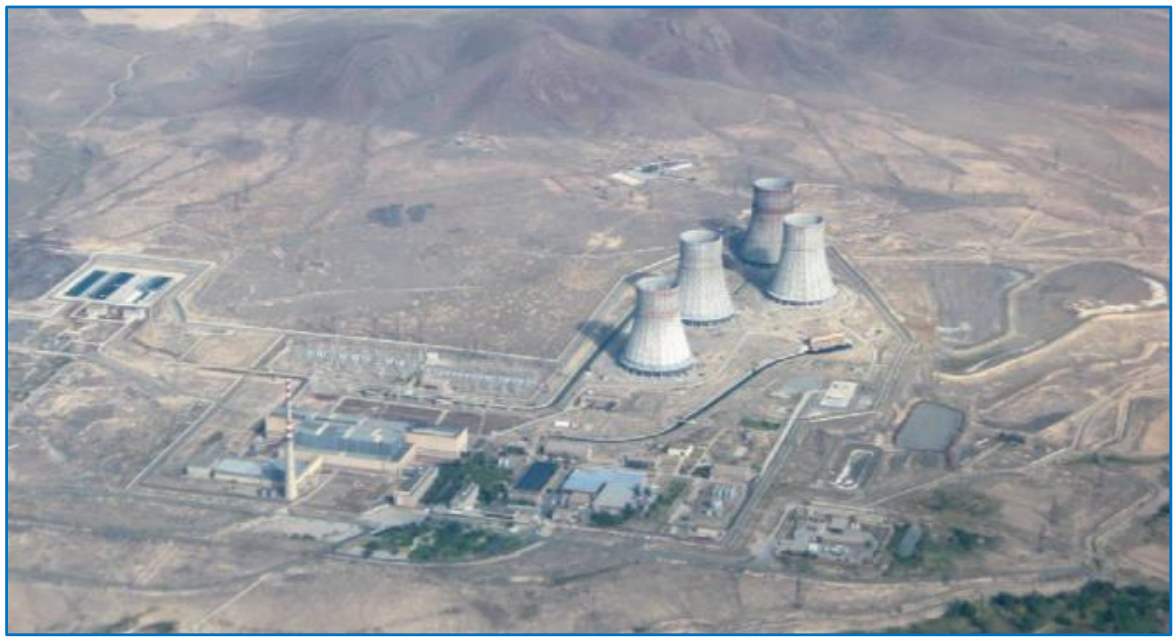

Şekil 5. Metsamor nükleer santrali (Gökeri vd., 2012)

1988 yllında Erivan'da meydana gelen deprem sonucunda zarar gören nükleer santralin kapatılmasına karar verilmiştir. Ancak Ermeni hükümeti enerji ihtiyaçlarını gerekçe göstererek bu santrali 1993 yılında yeniden açmaya karar vermiştir. 1995'de ise nükleer santralin ikinci reaktörü de üretime geçmiştir (Özdasli, 2016). Avrupa Birliği (AB), Metsamor Nükleer Santrali'nin güvenlik sorunları nedeniyle kapatılması gerektiğini ısrarla yinelemektedir. 1999'da Ermenistan hükümeti ile AB arasında Metsamor Nükleer Güç Santrali'nin 2004'e kadar mevcut faaliyetlerini durdurması konusunda bir anlaşma imzalanmıștır. Ayrıca Ermenistan AB konseyine üye olması halinde söz konusu santralin kapatılacağını taahhüt etmiştir. Ancak tüm bunlara rağmen enerji ihtiyaçlarını gerekçe gösteren Ermenistan hükümeti, Metsamor Santralinin faaliyetlerini sürdürmüştür. Bunun üzerine $\mathrm{AB}$, Metsamor Santralinin faaliyetlerinin durdurulması sonucunda ortaya çıkacak enerji ihtiyaçlarının karşılanması ve alternatif enerji kaynaklarının oluşturulması amaciyla Ermenistan yönetimine 100 milyon Euro tutarında bir destek verilmesini kararlaştırmıştır. Ancak, Ermenistan hükümeti bu miktarı yetersiz bulmuş ve AB'den bir milyar Euro talep etmiştir. Ermenistan yönetimi, söz konusu talebinin AB yönetimi tarafından kabul 
edilmemesi üzerine Metsamor Nükleer Santrali'ni kapatmayacağını ilân etmiştir. Metsamor santralinin 2031'e kadar faaliyetini sürdürebileceğini belirtilmektedir (Yüksel, 2014).

\subsection{Yeni Kurulacak Nükleer Güç Santralleri İçin Deprem Tehlikesi}

Nükleer güç santralleri için en önemli risklerden biri deprem ve depremin neden olduğu diğer zararlardır. Bu nedenle nükleer güç santralleri yapılacak olan bölgede bir takım ön çalışmaların yapılması gerekmektedir. Uluslararası Atom Enerjisi Ajansı'nın (IAEA) hazırlamış olduğu "Nükleer Tesislerin İnşaat Sahasındaki Deprem Tehlikesinin Değerlendirilmesi İçin Özel Güvenlik Rehberi" (SSG-09) başlıklı yönetmelikte nükleer güç santralleri sahasında deprem tehlikesini belirlemeye yönelik yapılacak saha çalıșmaları ile ilgili ayrıntılı bilgiler verilmiștir. Buna göre; bir nükleer güç santralinin deprem tehlikesinden etkilenme olasılığını hesaplamak için santral merkez kabul edilerek santralden $300 \mathrm{~km}$ uzaklığa kadar olan bölgede risk değerlendirmesi yapılması gerekmektedir. Bu kapsamda söz konusu alanda daha önce gerçekleşmiş depremlerin özelliklerinin, kuvvetli deprem oluşturma potansiyeli bulunan tüm aktif veya etkin fayların konumlarının, yaşlarının, zemin özellikleri ve toprak yapısı gibi birçok fiziksel, niteliksel ve niceliksel özelliğin incelenmesi gerekmektedir. Bu incelemeler yer bilimleri kapsamında yapılacak jeolojik, jeoteknik, jeodezik ve sismolojik çalışmalar ile çevresel etki değerlendirme çalışmalarını kapsamaktadır (IAEA, 2010).

Türkiye coğrafi ve jeolojik yapısı itibariyle, depremlerin sık yaşandı̆̆ı bir konumdadır. Dolayısıyla nükleer güç santrali gibi büyük mühendislik yapıları, deprem sonucunda oluşabilecek hasar ve yıkım riski ile karşı karşıyadır. Söz konusu yapıların yer seçiminde depremselliğin dikkate alınması olası zararların önüne geçmede en büyük koruyucu önlemlerden biridir. Ayrıca ülkemizde kurulması planlanan nükleer güç santralleri için deprem sonucu meydana gelebilecek nükleer kazalara yönelik risk değerlendirmelerinin yapılması gerekmektedir. $\mathrm{Bu}$ amaçla ülkemizde kurulması planlanan nükleer güç santralleri için çeşitli çalışmalar yapılmıştır. Akkuyu'da kurulması planlanan santral için 1975 yılından bu yana 200'ün üzerinde teknik rapor hazırlanmıștır. Bu raporların önemli bir bölümü depremsellikle ilgilidir (ETKB, 2015). Akkuyu nükleer güç santrali ile ilgili güncellenmiş yer raporu, ÇED raporu ve EPDK tarafından verilen elektrik üretim lisansı gibi işlemler tamamlanmış olup, tesisin inşaat çalışmaları devam etmektedir (TAEK, 2017; ETKB, 2018). Benzer şekilde Sinop'da kurulması planlanan santral için de TUBİTAK-MAM Çevre ve Temiz Üretim Enstitüsü tarafından yer değerlendirme parametrelerine yönelik araştırmalar yürütülmektedir (Karahan, 2018). Bu santral için ÇED başvuru dosyası hazırlanmış olup değerlendirme çalışmaları devam etmektedir. Üçüncü bir santralin kurulabilmesi için özellikle Trakya bölgesinde çalışmalar yoğunlaşmış olup İğneadaTekirdağ ekseni üzerinde araştırmalar devam etmektedir (İșeri ve Özen, 2013).

\subsection{Afet Yönetimi Kapsamında Yapılan Çalışmalar}

1986 yılında meydana gelen Çernobil faciasından etkilenen ülkeler, kazadan sonra oluşan nükleer kirlenme düzeyi ile ilgili araştırma yapma gereksinimi duymuşlardır. Bu kapsamda Türkiye'de mevcut radyoaktivitenin coğrafi dağılımını belirlemek, çevrenin doğal ve yapay radyasyon seviyesindeki değişimleri izlenmek ve kaza sonrası radyoaktif kirlenmenin miktarını belirlenmek amacıyla TAEK tarafından radyoaktivite izleme programı başlatılmıștır. 2002-2005 yılları arasında Şekil 6'daki haritada yer alan; Ağrl, Ardahan, Artvin, Bitlis, Edirne, Erzurum, Giresun, Hakkari, Iğdır, Kars, Kırklareli, Muş, Ordu, Rize, Samsun, Siirt, Şırnak, Tekirdağ, Trabzon ve Van illerinde, 2006 yilından itibaren de tüm Türkiye'yi kapsayacak şekilde toprak ve su numuneleri alınmıștır. 2002-2011 yılları arasında on yıl aralıksız ve tüm Türkiye sathında sürdürülen çalışmalarda; yüzey toprağındaki ve sudaki radyoaktivite seviyeleri belirlenmiştir (Oğuz vd., 2013).

Elde edilen sonuçlar, toprakta bulunan doğal radyonüklitlerin dünya ortalamasiyla uyumlu olduğunu, yağışlarla toprağa ulaşan yapay bir radyonüklit olan Cs-137'nin ise Çernobil kazası sonrası yağış alan bölgelerde gözlendiğini ortaya koymuştur. Ayrıca tüm ilçelerde analizi yapılan 
içme ve kullanma suyu numunelerine ilişkin toplam gösterge dozu değerlerinin, sınır değerin altında olduğu belirlenmiștir (Oğuz vd., 2013).

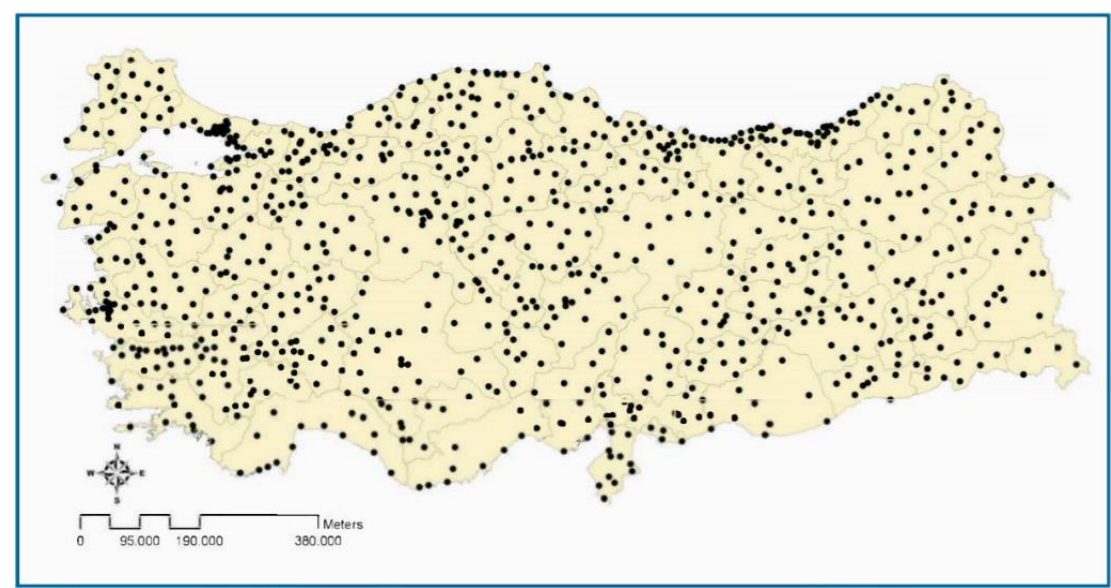

Şekil 6. Toprak ve su numune alınan il ve ilçeler (Oğuz vd., 2013).

Ülkemizde afet yönetimi kapsamında yapılan diğer bir önemli çalışma da Radyasyon Erken Uyarı Sistemi Ağı (RESA)'nın hayata geçirilmesidir. Ülkemiz topraklarını etkileyebilecek düzeyde radyoaktif madde salınımı olması durumunda uyarı verecek şekilde tasarlanan sistem; havadaki gama radyasyon seviyesinde meydana gelebilecek sıra dışı bir doz artışının algılanması esasına göre çalışmaktadır. Alınan veriler yardımıyla doğal doz hızı üzerindeki doz artışları belirlenebilmektedir. Ayrıca ülkemizdeki gama doz değeri bilgileri Avrupa Radyolojik Veri Değişim Platformu (EURDEP) ile sürekli olarak paylaşılmakta ve Avrupa Birliği ülkelerindeki meydana gelebilecek olası doz hızı artışları da takip edilebilmektedir. Şekil 7'de görülen RESA istasyonları, Trakya Bölgesinde Bulgaristan ve Romanya'da bulunan nükleer güç santrallerine yönelik olarak, Doğu Anadolu Bölgesinde ise Ermenistan'da bulunan nükleer güç santraline yönelik olarak oldukça sık bir şekilde yerleștirilmiștir. 18-ilçeye yeni kurulan RESA detektörleri ile toplam istasyon sayısı 211' e ulaşmıștır (TAEK, 2018).

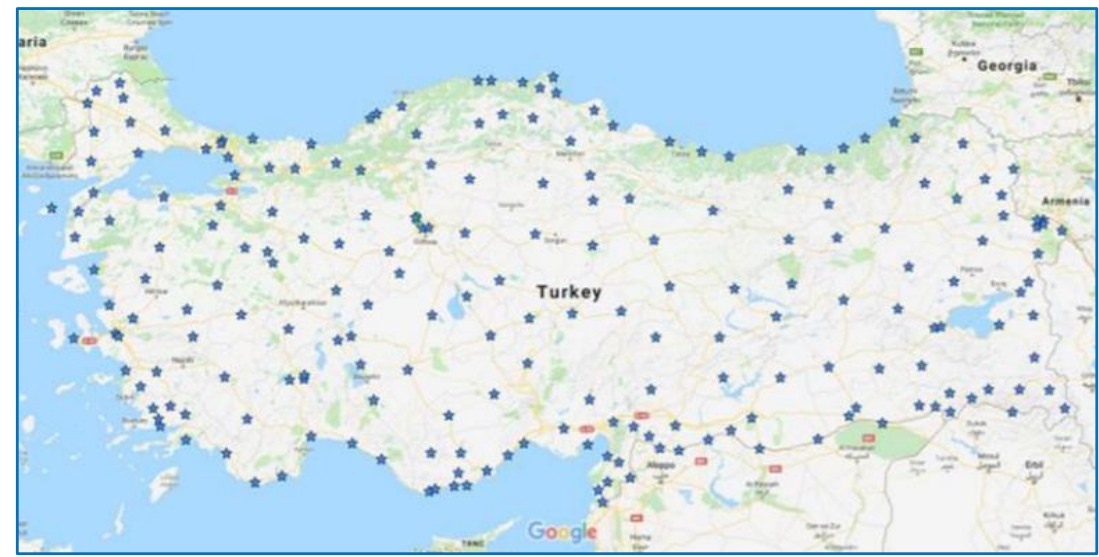

Şekil 7. RESA istasyonlarının Türkiye'deki dağılımı (TAEK, 2018)

RESA'nın benzeri olarak ülkemizin sınırlarında bulunan gümrük kapılarına, geçmesi muhtemel radyolojik veya nükleer maddeleri tespit etmek amacıyla 56 adet Radyasyon İzleme Sistemi (RİS) istasyonu kurulmuştur (Şekil 8). Bu sayede gümrük kapılarındaki radyoaktivite izlenebilmektedir (TAEK, 2018). 


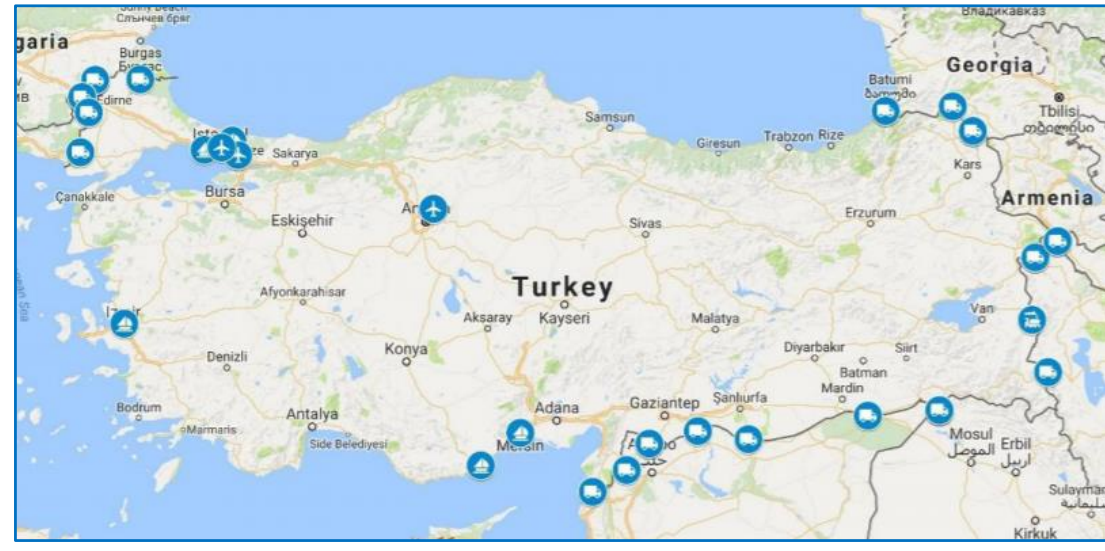

Şekil 8. RİS istasyonlarının Türkiye'deki dağılımı

Hem RESA hem de RíS istasyonları gama dozu değerinde artış olması halinde kontrol merkezine çevrimiçi uyarı gönderecek șekilde tasarlanmıştır. Acil durum anında TAEK kriz merkezine ve ilgili personele anlık olarak uyarı mesajı gönderilmektedir.

\section{SONUCLLAR}

Bu çalışmada öncelikle afet türleri hakkında açıklamalar yapılmış ve insan kaynaklı afetlerden biri olan nükleer kaynaklı kazalar ve bunların etkileri hakkında bilgiler verilmiștir. Ardından nükleer ve radyolojik tehlikeler ile bu tehlikelere karşı geliştirilen erken uyarı sistemlerinin önemi hakkında açıklamalar yapılmıştır. Ayrıca iyonize radyasyonun insan sağlığı üzerinde oluşturacağı zararlı etkiler ve geçmiște yaşanan nükleer kazalar değerlendirilmiștir. Son olarak, ülkemizin karşı karşıya olduğu nükleer ve radyolojik tehlikeler, komşu ülkelerde bulunan nükleer riskler ve deprem riskleri göz önüne alınarak belirlenmeye çalışılmıştır.

İyonize radyasyon, önlem alınmadığı durumlarda canlılar üzerinde büyük hasarlar oluşturabilecek radyasyon türüdür. Yüksek dozlarda iyonize radyasyon salınımı, nükleer silah denemeleri ve afet niteliğindeki nükleer kazalar sonucunda ortaya çıkabilmektedir. Geçmişte yaşanan deneyimler kontrolsüz salınan iyonize radyasyonun yıllar boyunca sürecek yıkıcı etkilere sahip olduğunu göstermiştir. Türkiye şu anda, sınırına yakın bölgelerde faaliyet gösteren nükleer güç santrallerinin oluşturduğu nükleer ve radyolojik tehlikelerle karşı karşıyadır. Ermenistan'da bulunan Metsamor Nükleer Santrali, eski bir teknolojiye sahip olması ve deprem bölgesinde bulunması nedeniyle Türkiye açısından en büyük nükleer tehdidi oluşturmaktadır.

Tüm mühendislik yapıları gibi nükleer santralleri de tehdit eden ve yıkıcı etkileri olabilen doğal kaynaklı afetlerin başında deprem gelmektedir. Fukuşima nükleer kazası, depremlerin nükleer santraller üzerinde yıkıcı etkileri olabildiğini göstermiştir. Türkiye'de can ve mal kayıplarına neden doğal afetlerin başında deprem yer almaktadır. Bu nedenle ülkemizde yeni kurulacak nükleer tesislerin yer seçimi ve inşası için gerekli olan teknik (jeolojik, jeofizik, jeoteknik, sismolojik vb.) çalışmaların ilgili uluslararası kuruluşların belirlediği standartlarda yapılmasının sağlanması oldukça önem arz etmektedir.

Ülkemiz sınırlarında faaliyet gösteren RESA istasyonları, nükleer bir kaza durumunu zamanında belirleme konusunda büyük bir avantaj sağlamaktadır. Bu sistem sayesinde, radyasyonun erken etkilerinin görüldüğü maruz kalma alanından uzaklaşmak için gerekli olan sürenin sağlanması mümkün olabilmektedir. Ancak yine de ortaya çıkacak radyoaktif serpintinin uzun süreli etkilerini engellemek mümkün görünmemektedir. Bu anlamda riskli bölgelerin acil olarak belirlenmesi ve zarar azaltıcı önlemlerin alınması zorunlu gözükmektedir. 
Metsamor Nükleer Santrali'nde meydana gelecek olası bir nükleer kaza durumunda Iğdır İlinin ve çevresinin büyük bir risk altında kalacağı değerlendirilmektedir. Söz konusu bölge için acil durum müdahale hususunda ilgili kurumların kabiliyetini ve farkındalığını arttıracak tatbikatlar organize edilmelidir. Bölge nüfusunun büyük bir bölümünün kırsal alanlarda yaşamakta olduğu göz önüne alındığında, Metsamor'a yakın bölgelerdeki yerleșim yerleri için bir acil durum uyarı sistemi oluşturulmasının yararlı olacağı düşünülmektedir. Ayrıca, Metsamor Nükleer Santrali'nde meydana gelebilecek bir nükleer kaza durumuna karşı, meteorolojik verileri de değerlendirerek, ülkemizin ne zaman ve ne ölçüde etkileneceğini tahmin edebilecek kaza simülasyonlarının hazırlanması ve bu simülasyon sonuçlarının araştırmacılar tarafından tartışılması, yararlı sonuçlar elde edilmesine katkı sağlayacaktır. Modern afet yönetim sistemi kapsamında uygulanacak tüm bu çalışmalar, CBS tabanlı karar destek sistemleri yardımıyla daha etkin bir şekilde gerçekleştirilebilir.

\section{KAYNAKLAR}

AFAD. (2014). 2014-2023 teknolojik afetler yol haritası belgesi https://www.afad.gov.tr/upload/Node/3906/xfiles/teknolojik-afetler-son.pdf . (Son Erişim Tarihi: 01.09.2018)

Arca, D. (2012). Afet Yönetiminde Coğrafi Bilgi Sistemi ve Uzaktan Algılama. Karaelmas Fen ve Mühendislik Dergisi, 2(2), 53-61.

Bodansky, D. (2007). Nuclear energy: principles, practices, and prospects: Springer Science \& Business Media.

Büyükkaraciğan, N. (2016). Türkiye'de Yerel Yönetimlerde Kriz ve Afet Yönetim Çalişmalarinin Mevzuat Açisindan Değerlendirilmesi. Selçuk Üniversitesi Sosyal ve Teknik Araștırmalar Dergisi(12), 195-219.

Coşkun, Ö. (2011). İyonize Radyasyonun Biyolojik Etkileri. SDU Teknik Bilimler Dergisi, 1(2).

Çerezcl, O., Yener, Ş. Ç., \& Çerezcl, F. (2017). Electromagnetic radiation interaction and pollution measurements. Paper presented at the Electric Electronics, Computer Science, Biomedical Engineerings' Meeting (EBBT), 2017.

Daşdağ, S. (2010). İyonlaştırıcı radyasyonlar ve kanser. Dicle Tıp Dergisi, 37(2).

Demirci, A., \& Karakuyu, M. (2004). Afet yönetiminde coğrafi bilgi teknolojilerinin rolü. Doğu Coğrafya Dergisi, 9(12).

Değer, A. (2010). NBC (nükleer, biyolojik, kimyasal) tehdidine topoğrafyanın etkilerinin araştırılması ve oluşacak radyoaktif yayılım için bir mekansal karar destek sistemi geliştirilmesi. Selçuk Üniversitesi Fen Bilimleri Enstitüsü.

Ekşi, A. (2017). Nükleer Kazalarda Olay Yeri Yönetimi. Hastane Öncesi Dergisi, 2(1), 51-62.

Enerji, T. C., \& Bakanlığı, T. K. (2015). Akkuyu Sahasında Depremsellik Riski Var mıdır?, https://nepud.enerji.gov.tr/tr-TR/Bilgi-Bankasi/Akkuyu-Sahasinda-Depremsellik-Riski-Varmidir. (son Erişim Tarihi: 30.08.2018)

Enerji, T. C., \& Bakanlığı, T. K. (2018). Akkuyu Nükleer Güç Santrali, https://nepud.enerji.gov.tr/trTR/Sayfalar/Akkuyu-Nukleer-Guc-Santrali-----, (Son Erişim Tarihi: 30.08.2018) 
Erdoğan, M. (2017). İyonlaştırıcı Radyasyon ve Korunma Yöntemleri. Selçuk Üniversitesi Fen Fakültesi Fen Dergisi, 43(2), 139-147.

Ergün, S., \& Polat, M. (2012). Nükleer enerji ve Türkiye'ye yansımaları. İnönü Üniversitesi Uluslararası Sosyal Bilimler Dergisi, 1(2), 34-58.

Erkal, T., \& Değerliyurt, M. (2009). Türkiye'de Afet Yönetimi. Doğu Coğrafya Dergisi, 14(22).

Eş, H., Mercan, S. I., \& Ayas, C. (2016). Türkiye için yeni bir sosyo-bilimsel tartışma: Nükleer ile yaşam. Turkish Journal of Education, 5(2), 47-59.

Galip, A. (2017). Küresel Isınma, Nedenleri ve Sonuçları. DTCF Dergisi, 46(2).

Gökeri, G., Gülay, Y., \& Demirel, H. (2012). Ermenistan'daki Metsamor nükleer santralinde meydana gelebilecek kaza sonrası doz seviyeleri için acil koruyucu önlemlerin belirlenmesi. Teknik Rapor. http://kurumsalarsiv.taek.gov.tr/bitstream/1/322/4/9999.pdf, 07.07.2018

Gökharman, D , Aydın, S , Koşar, P . (2016). Radyasyon Güvenliğinde Mesleki Olarak Bilmemiz Gerekenler. SDÜ Sağlık Bilimleri Dergisi, 7 (2), 35-40.

Günalp, B. (2017). Dünyada ve Ülkemizde Nükleer ve Radyolojik Kazaların Tarihçesi.

Güden, E , Öksüzkaya, A, Balcı, E , Tuna, R , Borlu, A , Çetinkaya, K . (2012). Radyoloji Çalışanlarının Radyasyon Güvenliğine İlişkin Bilgi, Tutum ve Davranıșı. Sağlıkta Performans ve Kalite Dergisi, 3 (1), 29-45.

Güneş, A. M. (2014). Uluslararası Hukuk Açısından Sınır Bölgelerinde Bulunan Nükleer Santraller. Türkiye Adalet Akademisi Dergisi, 17(1), 1-25.

Hodaloğulları Vatansever, Z. (2017). NÜKLEER SANTRALLERIN ENERJi GÜVENLİĞİNE ETKİSİ. Journal of International Social Research, 10(52).

IAEA. (2005). Chernobyl: The True Scale of the Accident. Retrieved from https://www.iaea.org/newscenter/pressreleases/chernobyl-true-scale-accident

IAEA. (2010). Seismic Hazards in Site Evaluation for Nuclear Installations Specific Safety Guide: IAEA Safety Standards Series No. SSG-9: International Atomic Energy Agency.

Işık, Ö., Aydınlığlu, H. M., Koç, S., Gündoğdu, O., Korkmaz, G., \& Ay, A. (2012). Afet yönetimi ve afet odaklı sağlık hizmetleri. Okmeydanı Tıp Dergisi, 28(2), 82-123.

İșeri, E , Özen, C . (2013). Türkiye'de Sürdürülebilir Enerji Politikaları Kapsamında Nükleer Enerjinin Konumu. Siyasal / Journal of Political Sciences, 0 (47).

Kadıoğlu, M. (2008). Modern, Bütünleşik Afet Yönetimin Temel İlkeleri. Afet Zararlarını Azaltmanın Temel İlkeleri, 1.

Kanl, İ. B., \& Ünal, Y. (2011). Üst düzey planlama sistemi ve afet yönetimi ilişkileri. İTÜDERGísí/a, $3(1)$. 
Karahan, H. (2018). Developing National Competence in Nuclear Energy: The Case of Turkey. In Turkish Economy (pp. 337-354). Palgrave Macmillan, Cham.

Kocaoğlu, N. K. (2010). Nükleer Tesis İşletenin Hukuki Sorumluluğu: Karşılaștırmalı ve Uluslararası Özel Hukuk Analizi. Ankara Barosu Dergisi(2), 33-112.

Korkusuz, M. H. (2012). Nükleer Santral İşletenin Hukuki Sorumluluğu. Beta.

Köklü, N. (2006). Radyasyonun İnsan Sağlığı Üzerindeki Etkileri ve Tıpta Uygulama Alanları. Selçuk Üniversitesi Fen Bilimleri Enstitüsü.

NEI. (2012). Comparing Fukushima and Chernobyl. Retrieved from https://www.nei.org/resources/fact-sheets/comparing-fukushima-and-chernobyl

Ocaktan, M. E., \& Akdur, R. (2008). Cep telefonu teknolojisi ve sağlık. Turkiye Klinikleri Journal of Medical Sciences, 28(1), 58-65.

Oğuz, F., Arıkan, İ. H., \& Yücel, B. (2013). Türkiye çevresel radyoaktivite atlası.

Özdasli, E. (2016). Kafkasya'nın Çernobıl'ı Metsamor Nükleer Santralı. Karadeniz Arastirmaları (50), 45.

Özgüner, F., \& Mollaoğlu, H. (2006). Manyetik Alanın Organizma Üzerindeki Biyolojik Etkileri. SDÜ Tıp Fakültesi Dergisi, 13(1).

Özkan, A. (2016). Güvenlik Paradigmasında Sınıraşan Bir Çevre Sorunsalı: "Nükleer Zarar" 1. Alternatif Politika, 8(1), 128.

Özmen, B., \& Özden, T. (2014). Türkiye'nin Afet Yönetim Sistemine İlişkin Eleștirel Bir Değerlendirme. İ.Ü. Siyasal Bilgiler Fakültesi Dergisi, 49, 1-28.

Saygın, H., Küpeli, T., Küçükşahin, A., \& Demir, A. (2006). Güvenlik Boyutunda Nükleer Enerjinin Sorunları ve Türkiye. Güvenlik Stratejileri Dergisi, 3(3), Sayfa 7-20 (14).

Serhatlıoğlu, S., Ozan, A., Gürsu, F., Gödekmerdan, A., Ayar, A., \& Oğur, E. (2004). İyonizan Radyasyonun Radyoloji Çalışanlarının Bağışıklık Düzeyleri Ve Kan Biyokimyası Üzerine Etkileri. Tanısal ve Girişimsel Radyoloji Dergisi, 10, 97-102.

Soykenar, M., \& Coşkun, S. (2015). Toplum ve sağlik etkileri yönüyle nükleer enerjiye genel bir bakış. TAF Preventive Medicine Bulletin, 14(1).

TAEK. (2017). Akkuyu Güncellenmiş Yer Raporu, http://www.taek.gov.tr/tr/2016-06-09-00-4355/44-akkuyu-nukleer-guc-santrali/419-akkuyu-guncellenmis-yer-raporu.html, (Son Erişim Tarihi: 31.08.2018)

TAEK. (2018). Türkiye Atom Enerjisi Kurumu 2017 Yılı Faaliyet Raporu.

Ülgen, S., Saygın, H., Or, İ., Kumbaroğlu, G., \& Atiyas, İ. (2011). Nükleer Enerjiye Geçişte Türkiye Modeli.

Varol, N , Kaya, Ç . (2018). Afet Risk Yönetiminde Transdisipliner Yaklaşım. Afet Ve Risk Dergisi, 1 (1), 1-8. 
Yaşar, S., Saygın, M., Kayan, M., \& Orhan, H. (2012). İyonize Radyasyonun Yaşam Kalitesi Üzerine Etkisi Effects of Ionizing Radiation on Quality of Life. Smyrna Tıp Dergisi, 3, 18-22.

Yüce, S. (2016). Düşük Doz Radyasyona Mesleki Olarak Maruz Kalmanın Genotoksikolojik Açıdan Değerlendirilmesi. Adnan Menderes Üniversitesi, Fen Bilimleri Enstitüsü.

Yüksel, M. (2014). Türk-Ermeni İlişkilerinde Başka Bir Sorun: Metsamor Nükleer Santrali ve Türkiye'ye Etkileri. Yeni Türkiye (60). 